\title{
Comparative Evaluation of Dietary Oregano, Anise and Olive Leaves in Laying Japanese Quails
}

-Author(s)

Christaki EV

Bonos EM

Florou-Paneri PC

Laboratory of Nutrition

Faculty of Veterinary Medicine

Aristotle University of Thessaloniki

Thessaloniki, Greece

\begin{abstract}
Aim of the present study was the comparative evaluation of the effect of ground oregano, anise and olive leaves as feed additives on performance and some egg quality characteristics of laying Japanese quails. A total of 189 Coturnix japonica quails (126 females and 63 males), 149 days old, were randomly allocated into seven equal groups with three subgroups of 9 birds each (6 females and 3 males). A commercial laying diet was fed to the control group. The remaining six groups were fed the same diet supplemented with oregano at 10 $\mathrm{g} / \mathrm{kg}$ or $20 \mathrm{~g} / \mathrm{kg}$, anise at $10 \mathrm{~g} / \mathrm{kg}$ or $20 \mathrm{~g} / \mathrm{kg}$ and olive leaves at $10 \mathrm{~g} /$ $\mathrm{kg}$ or at $20 \mathrm{~g} / \mathrm{kg}$. The birds were offered feed and water ad libitum for a period of 29 days, while being kept under commercial conditions. During the experiment, egg production, feed intake and mortality were recorded daily. At the end of the feeding period egg weight, egg yolk, albumen and eggshell weight percentages, egg yolk color (using the $L{ }^{*} a{ }^{*}$ color space) and blood serum triglycerides were determined. The diets supplemented with olive leaves $(10 \mathrm{~g} / \mathrm{kg}$ or $20 \mathrm{~g} / \mathrm{kg}$ ) resulted in a tendency $(p=0.054)$ for higher egg production percentage. Also, the color parameter $a^{*}$ was significantly $(p=0.001)$ higher in the eggs of quails that consumed oregano $(10 \mathrm{~g} / \mathrm{kg}$ or $20 \mathrm{~g} / \mathrm{kg})$ or olive leaves $(10 \mathrm{~g} / \mathrm{kg}$ or $20 \mathrm{~g} / \mathrm{kg})$.
\end{abstract}

\section{INTRODUCTION}

Herbs and spices have a traditional history of use in the nutrition of humans and animals. Today, in the search for natural feed additives in animal diets, many studies focus on the antioxidant (Botsoglou et al., 2002; Giannenas et al., 2005; Florou-Paneri et al., 2006), anticoccidial (Christaki et al., 2004; Florou-Paneri et al., 2004) or antimicrobial (Govaris et al., 2007; Botsoglou et al., 2010) properties of the plants. Consequently, such plants have attracted increasing interest as an alternative feeding strategy to replace antibiotic growth promoters.

Oregano (Origanum vulgare subsp. Hirtum) is a spice belonging to the Labiatae family, well known in Mediterranean countries. It contains a variety of bioactive components as carvacrol, thymol, $\gamma$-terpinene and p-cymene and exhibits considerable antimicrobial, antifungal and antioxidant activity (Giannenas et al., 2004, 2005; Florou-Paneri et al., 2005; Bampidis et al., 2006). In previous studies ground oregano has proven to be a promising dietary supplement mainly in poultry nutrition (Bampidis et al., 2005; Botsoglou et al., 2005).

Anise (Pimpinella anisum L.) is an annual aromatic plant belonging to the Apiaceae family. It is cultivated mainly in Southern Europe and Southeast Asia. Anise fruits or the so-called seeds are the used parts of the plant (Al-Beitawi et al., 2009). According to Franz et al. (2005) they contain 2-6\% essential oils, phenolic acids, eugenol, estragole 
and trans-anethole - a powerful phytoestrogen which is the main component of the oil (80-95\%). Anise has been used over the years for its antioxidant (Gulcin et al., 2003), antimicrobial (Al-Kassie, 2008), antibacterial (Tabanca et al., 2003) and antifungal (Soliman \& Badea, 2002) properties.

Olive leaves are agricultural residues from the beating of olive trees (Olea europea L.) for fruit harvest (Delgado Pertinez et al., 1998). They contain many substances, such as oleuropein, which is a bitter monoterpene glycoside and their most active compound, as well as verbascoside, lingstroside, tyrosol or hydroxytyrosol, oleanic and maslinic acids, luteolin, arigenine, olivine, olivine-diglucoside (Silva et al., 2006; Dekanski \& Janicijeniv-Hudomal, 2007). Most of the phenolic compounds have been shown to possess hypoglycemic and hypocholesteremic activities (Romani et al., 1999), to be potent antioxidants with anti-inflammatory properties (Benavente - Garcia et al., 2000), to have antimicrobial properties (Bisignano et al., 2001) and antiviral activity against DNA or RNA viruses (Fredrickson, 2000).

This study was designed to evaluate and compare the effects of the dietary use of oregano, anise and olive leaves in natural form on the performance and some egg quality characteristics of laying quails.

\section{MATERIALS AND METHODS}

\section{Plant material collection}

In this study, oregano consisted of flower tops and leaves of the plant. Moreover, from the anise plant, the seeds were used, whereas the olive leaves were collected from trees that were not treated with any chemicals for the last six months. All above plants of Greek origin were dried and ground before inclusion in the diets. Proximate analysis of oregano, anise and olive leaves, performed according to the guidelines of AOAC (2005), is presented in Table 1.

Table 1 - Chemical analysis of oregano, anise and olive leaves.

\begin{tabular}{lccc}
\hline & Oregano $\mathbf{~} / \mathbf{k g}$ & Anise $\mathbf{~ g / k g}$ & Olive leaves $\mathbf{~ g / k g}$ \\
\hline Dry matter & 883 & 935 & 937 \\
Crude protein & 108 & 129 & 79 \\
Crude fat & 64 & 138 & 21 \\
Crude fiber & 129 & 202 & 191 \\
Ash & 91 & 82 & 49 \\
\hline
\end{tabular}

\section{Birds and diets}

A total of 189 Coturnix japonica quails (126 females and 63 males), 149 days old, were randomly allocated into seven equal groups with three subgroups of 9 birds each ( 6 females and 3 males). All quails were individually weighed when placed in the cages, and their average weight did not differ $(p>0.100)$ between the seven groups. Quails were allowed to acclimatize for a period of 10 days, consuming a commercial laying diet in mash form ad libitum (Table 2). The same diet was fed to the control group (CONTR) during the experimental period. The remaining six groups were fed the above diet supplemented with $10 \mathrm{~g}$ oregano/kg (OREGA10), $20 \mathrm{~g}$ oregano/kg (OREGA20), $10 \mathrm{~g}$ anise/kg (ANISE10), $20 \mathrm{~g}$ anise/ $\mathrm{kg}$ (ANISE20), $10 \mathrm{~g}$ olive leaves/ $\mathrm{kg}$ (OLIVE10), or $20 \mathrm{~g}$ olive leaves $/ \mathrm{kg}$ (OLIVE20). Birds were offered feed and water ad libitum for a period of 29 days, while being kept under commercial conditions. Quails were handled according to the principles of the Greek Directorate General of Veterinary Services for the care of animals in experimentation.

Table 2 - Composition of basal diet.

\begin{tabular}{lccc}
\hline Ingredients & $\mathbf{g} / \mathbf{k g}$ & Chemical analysis & $\mathbf{g} / \mathbf{k g}$ \\
\hline Maize & 456.7 & Dry matter & 900 \\
Soybean meal & 305.4 & Crude protein & 198 \\
Wheat & 100.0 & Crude fat & 45 \\
Calcium carbonate & 62.1 & Crude fiber & 34 \\
Soybean oil & 30.0 & Ash & 94 \\
Corn gluten meal & 27.7 & Calculated \\
Dicalcium phosphate & 10.4 & analysis \\
Vitamin and trace mineral premix & 3.5 & Calcium \\
Salt & 2.1 & Total phosphorus & 26.0 \\
Sodium bicarbonate & 1.9 & Lysine \\
Methionine & 0.2 & Methionine \& & 10.2 \\
& \multicolumn{3}{c}{ Cystine } \\
\hline
\end{tabular}

1 - Supply per $\mathrm{kg}$ feed: $14000 \mathrm{IU}$ vitamin, $5000 \mathrm{IU}$ vitamin $\mathrm{D}^{3}, 30 \mathrm{mg}$ vitamin $E, 13 \mathrm{mg}$ vitamin $K, 3 \mathrm{mg}$ vitamin $B_{1}, 8 \mathrm{mg}$ vitamin $B_{2}, 3 \mathrm{mg}$ vitamin $\mathrm{B}_{6}, 20 \mu \mathrm{g}$ vitamin $\mathrm{B}_{12}, 85 \mathrm{mg}$ vitamin niacin, $20 \mathrm{mg}$ pantothenic acid, $2 \mathrm{mg}$ folic acid, $200 \mu \mathrm{g}$ biotin, $10 \mathrm{mg}$ vitamin C, $960 \mathrm{mg}$ choline chloride, $100 \mathrm{mg} \mathrm{Zn,} 116 \mathrm{mg} \mathrm{Fe}, 120 \mathrm{mg} \mathrm{Mg}, 20 \mathrm{mg} \mathrm{Cu}, 0.2 \mathrm{mg} \mathrm{Co}, 1$ $\mathrm{mg} \mathrm{l}, 0.3 \mathrm{mg} \mathrm{Se}$.

Throughout the experimental period, egg production, feed intake and mortality were recorded daily. At the end of the study, egg weight and egg yolk, albumen and eggshell (with shell membrane) weight percentages were determined in ten eggs per subgroup. Moreover, the egg yolk color was measured in a mixture of ten egg yolks from each subgroup using the $L^{*} a^{*} b^{*}$ color space $(L=$ lightness, $a=$ redness, $b=$ yellowness), according to Herber-McNeill \& Van Elswyk (1998), with the aid of a Konica Minolta Chroma Meter CR-410 (Japan). 
At the end of the feeding period, blood serum triglycerides were measured in six quail per group (two quail from each subgroup), according to Fossati \& Prencipe (1982), using a biochemical analyser Flexor E, Vital Scientific N.V. (Holland).

\section{Statistical analysis}

The statistical analysis was performed using the SPSS 16.0. 1 statistical package (SPSS Inc., Chicago, IL, USA). The one-way analysis of variance (ANOVA) for the seven groups of the experimentation was performed using the general linear model function of SPSS. Pearson's chi square test was used to analyze mortality. A value of $p \leq 0.050$ was considered significant and a value of $0.050<p \leq 0.100$ was considered a tendency. Levene's test was applied to test the homogeneity of the variances. Duncan's test was applied to determine statistical differences between the means.

\section{RESULTS AND DISCUSSION}

The effect of oregano, anise and olive leaves on egg production, daily feed intake and mortality of quails at the last day of the experimentation are presented in Table 3. A beneficial effect ( $p=0.054)$ was noticed on egg production of the groups OLIVE10 and OLIVE20 as compared to the remaining groups, except for the group OREGA10. Moreover, there was no egg production difference $(p>0.100)$ among OREGA10, OREGA20, ANISE10, ANISE20 and CONTR groups. There are no published data concerning the comparative use of oregano, anise and olive leaves in laying quail diets. As far as the use of olive leaves in quail nutrition is concerned, direct comparison with other studies cannot be made due to lack of pertinent reports. However, similar results were reported in laying hens fed olive pulp (Christaki et al., 1994). The benefits of dietary olive leaves are possibly due to the presence of polyphenols and particularly oleuropein, the main active component in this material (Malik \& Brandford, 2008). In previous studies relative to the supplementation of quail feeds with oregano only, no effect on egg production was found (Cetingul et al., 2007, 2009), whereas El-Deeb et al. (2007) reported that dietary anise decreased quail egg production.

As indicated in Table 3, there were no differences $(p>0.100)$ in daily feed intake between the dietary treatments over the experimental period. According to other researchers (Cetingul et al., 2007, 2009; Handl et al., 2008), oregano did not affect the daily feed intake in quails. On the other hand, Bayram et al. (2007) found that when anise was added to quail diets, feed intake increased. Moreover, there were no significant $(p>0.100)$ changes in mortality between the experimental groups, which is in agreement with Cetingul et al. (2009), who examined the dietary use of oregano in laying quails.

Table 3 - Performance of laying quail (mean \pm s.d).

\begin{tabular}{lccc}
\hline & Egg Production & Daily Feed Intake & Mortality \\
\hline Group ${ }^{1}$ & $\%^{2}$ & $\mathrm{~g}$ & $\%$ \\
CONTR & $70.88^{\mathrm{a}} \pm 11.51$ & $32.6 \pm 4.3$ & $0.0 \pm 0.0$ \\
OREGA10 & $79.89^{\mathrm{ab}} \pm 14.36$ & $31.2 \pm 2.6$ & $3.7 \pm 6.4$ \\
OREGA20 & $77.78^{\mathrm{a}} \pm 12.93$ & $30.0 \pm 1.5$ & $0.0 \pm 0.0$ \\
ANISE10 & $73.38^{\mathrm{a}} \pm 13.32$ & $28.6 \pm 4.0$ & $3.7 \pm 6.4$ \\
ANISE20 & $76.25^{\mathrm{a}} \pm 3.17$ & $29.3 \pm 0.5$ & $0.0 \pm 0.0$ \\
OLIVE10 & $95.01^{\mathrm{b}} \pm 3.27$ & $31.3 \pm 1.6$ & $0.0 \pm 0.0$ \\
OLIVE20 & $94.14^{\mathrm{b}} \pm 2.79$ & $33.6 \pm 1.4$ & $3.7 \pm 6.4$ \\
P value & 0.054 & 0.319 & 0.668 \\
\hline $1-$ - & &
\end{tabular}

1 - Groups: CONTR = control; OREGA10 $=10 \mathrm{~g}$ oregano/kg; OREGA20 $=20 \mathrm{~g}$ oregano $/ \mathrm{kg}$; ANISE10 $=10 \mathrm{~g}$ anise $/ \mathrm{kg} ;$ ANISE20 $=20 \mathrm{~g}$ anise $/ \mathrm{kg}$; OLIVE10 $=10 \mathrm{~g}$ olive leaves $/ \mathrm{kg} ;$ OLIVE20 $=20 \mathrm{~g}$ olive leaves $/ \mathrm{kg}$. 2Values in the same column with a superscript in common do not differ significantly at $\mathrm{P} \leq 0.100$

The effect of dietary treatments on some egg quality traits is shown in Table 4. There were no significant $(p>0.100)$ differences in egg weight and yolk, albumen and shell weight percentage between the seven groups. Cetingul et al. $(2007,2009)$ also reported no significant effect on egg weight when oregano was incorporated in quail diets. Bayram et al. (2007) observed that egg weight was reduced when anise was used as dietary supplement in laying quails. Eggs from quails fed either oregano or olive leaves at levels of $10 \mathrm{~g} / \mathrm{kg}$ and $20 \mathrm{~g} / \mathrm{kg}$ presented significantly $(p=0.001)$ different yolk color as compared to the other groups, since $a^{*}$ color value was higher, shifting towards red. This increase in yolk $a^{*}$ values might be due to the passage of pigments contained in the plants included in the diet into the egg yolk. No significant $\left(p>0.100\right.$ ) differences on $L^{*}$ and $b^{*}$ values were observed between all the dietary treatments. There is little information published on the effect of dietary oregano, on yolk color index of quail eggs. Cetingul et al. (2009) mentioned that the addition of oregano in quail feeds had no influence on yolk color. Moreover, there are no literature data relative to the effect dietary anise and olive leaves on yolk color of laying quails.

Serum total triglycerides values $(\mathrm{mg} / \mathrm{dl})$ were $257.0 \pm 74.8,219.7 \pm 33.7,144.7 \pm 109.0,131.0 \pm 17.3$, $213.3 \pm 94.5,262.3 \pm 30.3$ and $163.3 \pm 35.1$ (mean \pm sd) for the quails of groups CONTR, OREGA10, OREGA20, ANISE10, ANISE20, OLIVE10 and OLIVE20, respectively, 
Table 4 - Quail egg quality parameters (mean \pm s.d).

\begin{tabular}{|c|c|c|c|c|c|c|c|}
\hline \multirow{2}{*}{ Group ${ }^{1}$} & \multirow{2}{*}{ Egg weight } & \multirow{2}{*}{ Egg yolk g } & \multirow{2}{*}{ Egg albumen $\%$} & \multirow{2}{*}{ Egg shell\% } & \multicolumn{3}{|c|}{ Yolk Colour\% } \\
\hline & & & & & $L^{*}$ & $a * 2$ & b* $^{*}$ \\
\hline CONTR & $11.95 \pm 0.02$ & $31.39 \pm 0.48$ & $54.10 \pm 1.41$ & $14.52 \pm 0.99$ & $68.80 \pm 0.41$ & $2.16 \mathrm{a} \pm 0.74$ & $64.13 \pm 0.35$ \\
\hline OREGA10 & $12.27 \pm 1.03$ & $32.42 \pm 1.06$ & $53.35 \pm 0.97$ & $14.24 \pm 1.36$ & $69.24 \pm 2.46$ & $4.30 b \pm 0.29$ & $66.65 \pm 3.01$ \\
\hline OREGA20 & $11.64 \pm 0.48$ & $31.79 \pm 0.83$ & $53.67 \pm 1.08$ & $14.53 \pm 0.71$ & $67.50 \pm 0.76$ & $3.76 b \pm 0.97$ & $64.68 \pm 0.65$ \\
\hline ANISE10 & $11.63 \pm 0.26$ & $32.59 \pm 0.85$ & $53.04 \pm 0.82$ & $14.38 \pm 0.19$ & $70.19 \pm 0.31$ & $1.85 a \pm 0.65$ & $65.85 \pm 1.01$ \\
\hline ANISE2O & $11.82 \pm 0.04$ & $32.01 \pm 0.95$ & $54.07 \pm 1.62$ & $13.92 \pm 0.79$ & $69.97 \pm 0.90$ & $2.37 a \pm 0.13$ & $66.25 \pm 1.42$ \\
\hline OLIVE10 & $11.99 \pm 0.25$ & $31.64 \pm 0.48$ & $53.54 \pm 0.54$ & $14.82 \pm 0.82$ & $69.60 \pm 1.70$ & $3.60 b \pm 0.75$ & $66.00 \pm 1.32$ \\
\hline OLIVE20 & $12.04 \pm 0.47$ & $31.53 \pm 0.94$ & $53.49 \pm 0.78$ & $14.98 \pm 0.44$ & $69.56 \pm 1.26$ & $4.25 b \pm 0.53$ & $67.38 \pm 1.69$ \\
\hline P value & 0.695 & 0.515 & 0.888 & 0.764 & 0.288 & 0.001 & 0.243 \\
\hline
\end{tabular}

1 - Groups: CONTR = control; OREGA10 $=10 \mathrm{~g}$ oregano/kg; OREGA20 $=20 \mathrm{~g}$ oregano $/ \mathrm{kg} ;$ ANISE10 = $10 \mathrm{~g}$ anise $/ \mathrm{kg} ;$ ANISE20 = $20 \mathrm{~g}$ anise $/ \mathrm{kg} ;$ OLIVE10 $=10 \mathrm{~g}$ olive leaves $/ \mathrm{kg} ;$ OLIVE20 $=20 \mathrm{~g}$ olive leaves $/ \mathrm{kg}$. 2 - Values in the same column with a superscript in common do not differ significantly at $\mathrm{P} \leq 0.001$.

and did not differ significantly $(p>0.100)$ between the groups.

\section{CONCLUSIONS}

Results of this study showed that there were no adverse effects from the dietary inclusion of oregano, anise and olive leaves in laying quail feeds. However, dietary olive leaves $(10 \mathrm{~g} / \mathrm{kg}$ and $20 \mathrm{~g} / \mathrm{kg})$ improved egg production and increased the $a^{*}$ value of the yolk colour. Also, dietary oregano $(10 \mathrm{~g} / \mathrm{kg}$ and $20 \mathrm{~g} / \mathrm{kg})$ increased the $a^{*}$ value of the yolk colour. Therefore, the use of herbal natural feed additives to benefit laying quail performance and egg quality seems to be promising.

\section{REFERENCES}

Al-Beitawi NA, El-Ghousein SS, Abdullah HN. Antibiotic growth promoters and anise seeds in broiler diets. Jordan Journal of Agricultural Sciences 2009; 5(4):472-481.

Al-Kassie GAM. The effect of anise and rosemary on broiler performance. International Journal of Poultry Science 2008; $7(3): 243-245$.

AOAC. Official Methods of Analysis. 18 $8^{\text {th }}$ ed. Association of Analytical Chemists, AOAC International, Arlington Virginia, USA; 2005.

Bampidis VA, Christodoulou V, Florou-Paneri P, Christaki E, Chatzopoulou PS, Tsiligianni T, Spais AB. Effect of dietary dried oregano leaves on growth performance, carcase characteristics, and serum cholesterol of female early-maturing turkeys. ritish Poultry Science 2005; 46(5):595-601.

Bampidis VA, Christodoulou V, Florou-Paneri P, Christaki E. Effect of dried oregano leaves versus neomycin against diarrhea from Escherichia coli in newborn calves. Journal of Veterinary Medicine Series A 2006; 53(3):154-156.

Bayram I, Cetingul SI, Akkaya B, Uyarlar C. Effect of aniseed (Pimpinella anisum L.), on egg production, quality, cholesterol levels, hatching results and the antibody values in blood of laying quails (Coturnix coturnix japonica). Archiva Zootechnica 2007; 10:73-77.

Benavente-Garcia O, Castillo J, Lorente J, Ortuno A, Del Rio JA. Antioxidant activity of phenolics extracted from Olea europaea L. leaves. Food Chemistry 2000; 68:457-462.

Bisignano G, Lagana MG, Trombetta D, Arena S, Nostro A, Uccella N, Mazzanti G, Saija A. In vitro antibacterial activity of some aliphatic aldehydes from Olea europaea L. FEMS Microbiology Letters 2001; 198:9-13.

Botsoglou E, Govaris A, Christaki E, Botsoglou N. Effect of dietary olive leaves and/or $\alpha$-tocopheryl acetate supplementation on microbial growth and lipid oxidation of turkey breast fillets during refrigerated storage. Food Chemistry 2010; 121(1):17-22.

Botsoglou N, Florou-Paneri P, Botsoglou E, Dotas V, Giannenas I, Koidis A, Mitrakos P. The effect of feeding rosemary, oregano, saffron and $\alpha$-tocopheryl acetate on hen performance and oxidative stability of eggs. South African Journal of Animal Science 2005; 35(3):143-151

Botsoglou NA, Christaki E, Fletouris DJ, Florou-Paneri P, Spais AB. The effect of dietary oregano essential oil on lipid oxidation in raw and cooked chicken during refrigerated storage. Meat Science $2002 ; 62: 259-265$.

Cetingul IS, Bayram I, Akkaya B, Uyarlar C, Yardimci M, Sahin $\mathrm{EH}$, Sengor E. Utilisation of oregano (Origanum vulgaris) in laying quails (Coturnix coturnix japonica) (2): The effects of oregano on performance, carcass yield, liver and some blood parameters. Archiva Zootechnica 2007; 10:57-65.

Cetingul IS, Bayram I, Yardimci M, Sahin EH, Sengor E, Akkaya B, Uyarlar C. Effects of oregano (Oregano Onites) on performance, hatchability and egg quality parameters of laying quails (Coturnix Coturnix japonica). Italian Journal of Animal Science 2009; 8:467-477.

Christaki E, Florou-Paneri P, Giannenas I, Papazahariadou M, Botsoglou NA, Spais AB. Effect of a mixture of herbal extracts on broiler chickens infected with Eimeria tenella. Animal Research 2004; 53:137-144.

Christaki E, Yannakopoulos AL, Florou-Paneri P, Kufidis D, Georgopoulou IE. Effect of olive pulp on the performance of laying hens. Proceedings of the $9^{\text {th }}$ European Poultry Conference; 1994 Aug 7-12; Glasgow.GB. v.1, p.501-502. 
Dekanski D, Janicijevic-Hudomal S. Medicinal features of olive leaf (Olea europaea L.). Praxis Medica 2007; 35(1-2):89-92.

Delgado Pertinez M, Chesson A, Provan GJ, Garrido A, GomezCabrera A. Effect of different drying systems for the conservation of olive leaves on their nutritive value for ruminants. Annales De Zootechnie 1998; 47:141-150.

El-Deeb MA, Metwally MA, Galal AE. The impact of botanical extract, capsicum (Capsicum frutescence L.), anise and molukhyia (Corchorus olitorius) supplementation and their interactions on productive and reproductive performance of Japanese quail (Coturnix japonica). $4^{\text {th }}$ World Poultry Conference; 2007 March 2730; Sharm El-Seikh. Egypt. p. 455-464.

Florou-Paneri P, Christaki E, Giannenas I, Papazahariadou M, Botsoglou NA, Spais AB. Effect of dietary olympus tea (Sideritis scardica) supplementation on performance of chickens challenged with Eimeria tenella. Journal of Animal and Feed Sciences 2004; 13:303-313.

Florou-Paneri P, Giannenas I, Christaki E, Govaris A, Botsoglou N. Performance of chickens and oxidative stability of the produced meat as affected by feed supplementation with oregano, vitamin $C$, vitamin $E$ and their combinations. Archiv für Geflüeglekunde 2006; 70(5):232-240.

Florou-Paneri P, Nikolakakis I, Giannenas I, Koidis A, Botsoglou E, Dotas V, Mitsopoulos I. Hen performance and egg quality as affected by dietary oregano essential oil and $\alpha$-tocopheryl acetate supplementation. International Journal of Poultry Science 2005; 4(7):449-454.

Fossati P, Prencipe L. Serum triglycerides determined colorimetrically with an enzyme that produces hydrogen peroxide. Clinical Chemistry $1982 ; 28: 2077-2080$.

Franz C, Bauer R, Carle R, Tedesco D, Tubaro A, Zitteri-Eglseer K. Study of the assessment of plants/herb extracts and their naturally or synthetically produced components as "additives" for use in animal production. CFT/EFSA/FEEDAP/2005/01.

Fredrickson WR. Method and composition for antiviral therapy with olive leaves. United States patent 20006117844. 2000 set 12. 6,117,844; 2000.

Giannenas I, Florou-Paneri P, Papazahariadou M, Botsoglou NA, Christaki E, Spais AB. Effect of diet supplementation with ground oregano on performance of broiler chickens challenged with imeria tenella. Archiv für Geflüeglekunde 2004; 68(6):247-252.

Giannenas IA, Florou-Paneri P, Botsoglou NA, Christaki E, Spais AB. Effect of supplementing feed with oregano and/or $\alpha$-tocopheryl acetate on growth of broiler chickens and oxidative stability of meat. Journal of Animal and Feed Sciences 2005; 14:521-535.

Govaris A, Florou-Paneri P, Botsoglou E, Giannenas I, Amvrosiadis I, Botsoglou N. The inhibitory potential of feed supplementation with rosemary and/or $\alpha$-tocopheryl acetate on microbial growth and lipid oxidation of turkey breast during refrigerated storage. LWT-Food Science and Technology 2007; 40(2):331-337. antioxidant and antimicrobial activities of anise (Pimpinella anisum L.) seed extract. Food Chemistry 2003; 83:371-382.

Handl S, Hellweg P, Khol-Parisini A, Rossmann B, Thurner K, Luf W, Novak J, Zentek J. Effect of oregano (O. majorana $x$ O. vulgare) on performance and antioxidative capacity of quails fed a diet rich in 3 fatty acids. Journal of Animal Physiology and Animal Nutrition 2008; 92:242-245.

Herber-McNeill SM, Van Elswyk ME. Dietary marine algae maintains egg consumer acceptability while enhancing yolk colour. Poultry Science 1998; 77:493-496.

Malik NSA, Bradford JM. Recovery and stability of oleuropein and other phenolic compounds during extraction and processing of olive (Olea europaea L.) leaves. Journal of Food, Agriculture and Environment 2008; 6(2):8-13.

Romani A, Mulinacci N, Pinelli P, Vincieri F, Cimato A. Polyphenolic content in five tuscany cultivars of Olea europaea L. Journal of Agricultural and Food Chemistry 1999; 47:964-967.

Silva S, Gomes L, Leitao F, Coelho AV, Vilas Boas L. Phenolic compounds and antioxidant activity of Olea europaea L. fruits and leaves. Food Science and Technology International 2006; 12:385-395.

Soliman KM, Badea RI. Effect of oil extracted from some medicinal plants on different mycotoxigenic fungi. Food and Chemical Toxicology 2002; 40:1669-1675.

Tabanca N, Bedir E, Kirimer N, Baser KH, Khan SI, Jacob MR, Khan IA. Antimicrobial compounds from Pimpinella species growing in Turkey. Planta Medical 2003; 69:933-938. 


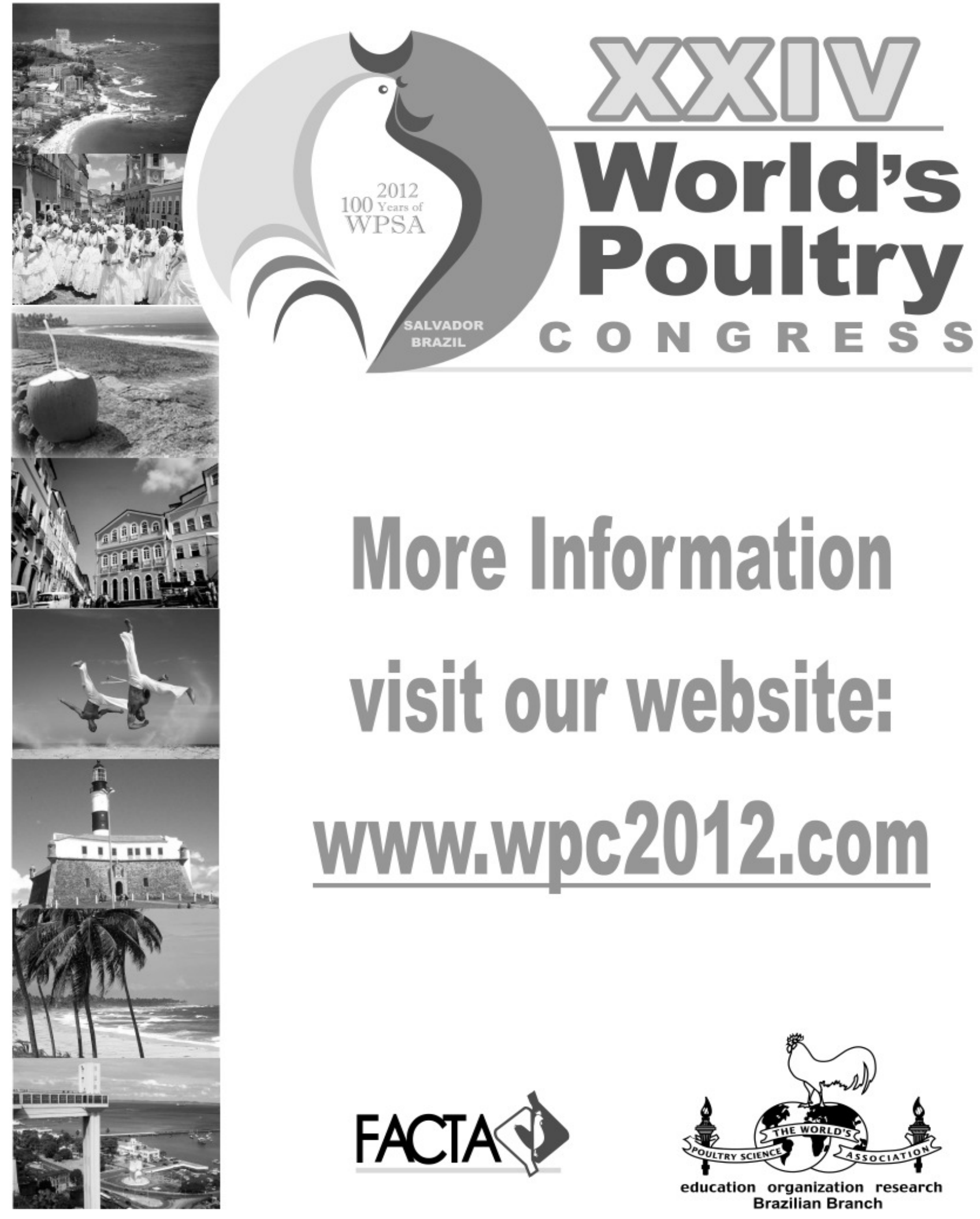

\section{WWW.WPC2012.COM}

